Nora Elise Hesby Mathé

Department of Teacher Education and School Research

University of Oslo

Email: $\underline{\text { n.e.h.mathe@ils.uio.no }}$

\title{
Students' Understanding of the Concept of Democracy and Implications for Teacher Education in Social Studies
}

\begin{abstract}
According to recent studies, Norwegian students are knowledgeable about and show strong support for democracy, as well as demonstrate democratic attitudes. These qualities must be actively encouraged and maintained also in successful democracies. Little is known, however, about how students understand and explain democracy as a subject-specific concept. Such knowledge may be valuable for social studies teachers and teacher educators to fulfil the purpose of the social studies curriculum. The present article investigates 16-year-old students' understanding of the concept of democracy. In social studies, the concept of democracy is essential not only for disciplinary understanding and discourse, but also for students' out-of-school democratic participation. To investigate students' understanding of this concept, semi-structured group interviews were conducted with a total of 23 students at three different Norwegian upper secondary schools. A central finding is that students primarily expressed a liberal understanding of democracy focusing on voting in elections as the main political activity. Students also demonstrated more or less limited or elaborate understanding. In addition to presenting and discussing students' understandings of the concept of democracy, this article considers implications for teacher education in social studies. One implication is that teacher educators need to engage actively in discussing and defining core concepts with their students. This is related to supporting student teachers' professional development and in turn developing adolescents' opportunities for democratic participation. Such a dual focus can provide a knowledge base to help student teachers in their professional development in their first years as practicing teachers.
\end{abstract}

Keywords: democracy, concepts, understanding, teacher education, social studies, democratic theory

\section{Sammendrag}

Tidligere studier viser at norske skoleelever er kunnskapsrike om og viser sterk støtte til demokrati, og gir uttrykk for sentrale demokratiske holdninger. Vi vet at det må arbeides aktivt for å opprettholde disse kvalitetene, selv i stabile demokratier. Vi vet imidlertid lite om hvordan elever forstår og forklarer demokrati som fagbegrep. Dette er kunnskap som kan være verdifull for larere og larerutdannere i arbeidet for å oppfylle læreplanens formål i samfunnsfaget. I samfunnskunnskap er ikke demokratibegrepet bare sentralt for forståelse og deltakelse i faget, men også for elevers demokratiske deltakelse utenfor skolen. Denne artikkelen undersøker norske 16-åringers forståelse av demokratibegrepet, og bygger på semi-strukturerte gruppeintervjuer med til sammen 23 elever fra tre videregående skoler. Et sentralt funn er at elevene først og fremst uttrykker en liberal forståelse av demokrati med fokus på stemmegivning i valg som den viktigste formen for politisk deltakelse. I tilknytning til 
dette kan elevene sies å vise mer eller mindre begrenset eller utvidet forståelse av begrepet. I tillegg til å presentere og diskutere elevers forståelse av begrepet demokrati, ser denne artikkelen på mulige implikasjoner for læererutdanning i samfunnskunnskap. Én implikasjon er at lcererutdannere aktivt bør involvere lcrerstudentene i å diskutere og definere sentrale begreper. Dette kan være med på å støtte larerstudentenes profesjonelle utvikling, og, gjennom dette, utvikle ungdommers muligheter for demokratisk deltakelse. Et slikt dobbelt fokus kan bidra med en kunnskapsbase som hjelper lererstudenter i deres første år som praktiserende larere.

Nøkkelord: demokrati, begreper, forståelse, larerutdanning, samfunns-kunnskap, samfunnsfag

\section{Introduction}

Democracy is the frame for politics in Norway and about half the world's countries (The Economist Intelligence Unit, 2014). The institutions and practices of democracy create the political space in which we as citizens form our identities and exercise our rights. Political theorist Bernard Crick (2008) stated, "Democracy is both a sacred and a promiscuous word. We all love her but we see her differently. She is hard to pin down. Everyone claims her but no one can possess or even name her fully" (p. 13). These words illustrate both the importance and the intrigue of studying the concept of democracy in an educational context. All education in Norway, including teacher education, is mandated to promote democracy, and the concept of democracy is central in social studies.

Empirical research has produced substantial knowledge about students' support for democratic values, and their current and envisioned civic and political participation (Mikkelsen, Fjeldstad, \& Lauglo, 2011; Schulz, Ainley, Fraillon, Kerr, \& Losito, 2010; Torney-Purta, 2002). Less research, however, has investigated how adolescents understand the concept of democracy itself; that is, how they answer the question: what is democracy? ${ }^{1}$ The purpose of this article is to present and discuss Norwegian 16-year-olds' conceptions of democracy. Knowledge about students' conceptions of democracy can inform teaching and learning in social studies on all levels of the educational system. Based on this research, this article introduces the notions of limited and elaborate understanding of democracy, and argues the importance of incorporating conceptions of democracy in social studies in teacher education programmes.

Studies of people's various ideas about and relations to democracy can be placed in two categories: (a) citizenship education, dealing primarily with attitudes toward, practices in and knowledge about democracy, and (b) studies focusing on people's conceptions and understanding of democracy. In this study, a concept is understood as an idea, principle or category (Concept, 2015; 
Tjønneland, 2011), and the terms understand and conception are used to describe the explanation students give for a concept.

The International Civic and Citizenship Education Study (ICCS), consisting of 38 national case studies followed by international comparative analyses, made important contributions to the field of citizenship education. The 2009 ICCS study found that a majority of students endorsed democratic values and intended to exercise their democratic right to vote in future national elections. However, the study found considerable variation across and within countries concerning students' levels of civic knowledge (Schulz et al., 2010). Mikkelsen et al. (2011), who conducted the national investigation in Norway, found that Norwegian students demonstrated somewhat stronger support for democratic values than the international mean value. They strongly supported a representative form of democracy and expressed support for more participatory forms of citizenship.

As Canache (2012) noted, many studies have investigated people's beliefs and democratic values, principles and participation, but few have addressed the question of how the average citizen understands democracy. However, some studies have sought to explore what citizens in developing countries understand by democracy (e.g., Canache, 2012; Dalton, Shin, \& Jou, 2007; Ottemoeller, 1998). These studies have shown that people largely embrace a liberal definition of democracy, focusing on various rights and liberty. In Dalton et al.'s (2007) study, references to democratic procedures and institutions (e.g., elections, majority rule) occurred less often than references to freedom and liberty. Their international survey found that high levels of democracy were related to a greater emphasis on freedom and liberty, implying that participants in good democracies emphasise democratic values when asked to explain what democracy means to them. This difference illustrates how people's understanding of concepts like democracy varies with context and what they view as 'normal' (Davies \& Lundholm, 2011), and that citizens' democratic experiences influence their perceptions of the central features of democracy (Moodie, Markova, \& Plichtova, 1995).

Concerning youth, the results of the 1971 Civic Education Study indicated that students viewed democracy as giving people a chance to voice their opinions (Torney, Oppenheim, \& Farnen, 1975), while later studies found that Western youth associated democracy with related concepts such as individual freedom, individual rights and voting (e.g., Moodie et al., 1995; Sigel \& Hoskin, 1981; Szalay \& Kelly, 1982). More recently, a Swedish study found that adolescents in 2003 had a quite uniform understanding of democracy, focusing on everybody's opportunities to participate in decision-making through voting, basic political rights and the election of representatives to govern at the national level (Arensmeier, 2010).

This review demonstrates that, in Norway, we primarily have knowledge about conditions for citizenship education in schools and about young people's 
knowledge of and attitudes toward democracy. We do not know much about how Norwegian youth understand the concept of democracy: What is democracy? How does it work? What are the most important characteristics and features of democracy? These are the questions of interest in this article. These questions are important because how students perceive the notion of democracy has implications both for social studies education and for the likelihood of students wishing to help develop the democracies they are a part of (Canache, 2012). The focus of this article relates to conceptions of democracy as expressed in qualitative group interviews in the context of social studies in upper secondary school, which will be elaborated below.

Based on the identified needs for research on students' understanding of the concept of democracy, the following research question has been defined:

How do Norwegian 16-year-olds explain their understanding of the concept of democracy?

In the following, I discuss how I have framed this study theoretically and methodologically.

\section{Theoretical Framework}

The conceptual framework of this study builds on (a) democratic theory concerning how democracy can be understood in terms of a political system of government in modern nation-states, and (b) the Norwegian context, including a brief overview of the goals of education concerning democracy in schools. These contributions will be used to discuss the participating students' conceptions of democracy.

\section{Democratic Theory}

The term democracy has various contested meanings. At its core is the idea of a government involving some form of "rule by the people" and a society that allows and upholds this practice (e.g., Behrouzi, 2005; Dahl, 2001; Nguyen, 2014). In modern nation-states, democracy is primarily representative; adult citizens choose their representatives in local and national elections.

This framework is based on three ideas of democracy prevalent in democratic theory; liberal (competitive) democracy, participatory democracy and deliberative democracy. These three strands offer different views on the citizen's role in a democracy and on the relationship between the state and its citizens.

First, a liberal (competitive) view of democracy focuses on individual citizens and their preferences, instead of the 'common good'. Citizens function primarily as voters, and politicians are their representatives, defending their 
positions and competing for votes (e.g., Schumpeter, 1994). Tightly interwoven with this individualistic conception of politics is the importance of individual rights, intended to secure citizens' freedom (Behrouzi, 2005; Rasch, 2004; Terchek \& Conte, 2001). Behrouzi (2005) argued this view of democracy is a distortion of the "original" idea of democracy as "rule by the people". He employed the phrase "audience democracy" to show that the role of the electorate is primarily "reactive"; it is left to respond to issues pre-defined by opinion polls, mass media and representatives through "political marketeering" (p. 156). This critique is representative of several arguments against competitive conceptions of democracy in modern democratic theory.

The second core idea is participatory democracy. Behrouzi (2005) viewed the task of "rescuing the true meaning of democracy" (p. 168) as the most important aspect of the project of participatory democracy in the 1960s and '70s. The central idea is that free and fair voting in elections is not enough: a true democracy requires higher levels of citizen intervention and influence on decisions (e.g., Barber, 1984; Dewey, 1927; Pateman, 1970). Rasch (2004) argued that, in a participatory perspective, democracy must be seen as a goal in itself by contributing to its members' self-realisation. The idea that active participation will help create truly democratic citizens is essential in Pateman's (1970) work on participation in local and micro processes in workplaces, and in Dewey's (1927) emphasis on expanded opportunities for participation. Dewey also challenged the idea of majority rule, claiming that the important issue is how a majority becomes a majority and the antecedent processes.

Third, the idea of deliberative democracy began to develop from the early 1990s. Theories of deliberative democracy arose from participatory democracy in the notion that decision-making processes require deliberation. Deliberative democratic processes are considered to transform individuals' preferences and opinions to some sort of "morally and rationally justifiable and convergent positions” (Behrouzi, 2005, p. 176). According to Behrouzi (2005), the primary driving forces behind these transformations are the power of reason, participants' morals and consideration of the common good, as well as the idea that decision-making is first and foremost consensus-building (Cohen, 2002; Habermas, 1995).

These conceptions deal with democracy both as a theoretical ideal and with reactions to democracy in practice. Based on work addressing the quality of democracy, Munck (2014) discussed a minimal and a broadened definition of democracy, meant to unite the two perspectives. His minimal definition was "electoral democracy", while his expanded definition suggested that democracy includes political freedom, political equality, government decision-making and the social environment of politics. Table 1 presents the analytical concepts I have deduced from this theoretical framework. 


\section{The Norwegian Context}

Norway can be characterised as a stable representative democracy founded on a parliamentary and multi-party system in a unitary state. This, alongside features of the Norwegian system concerning the relationship between the people and their representatives and between the government, opposition and pressure groups, has caused experts to describe Norway as an example of the Nordic model of government (Arter, 1999) and as a consensual democracy (Lijphart, 1999). In recent years, some have argued that the Norwegian representative democracy is eroding (Selle \& Østerud, 2006; Østerud \& Selle, 2006). An important factor of this erosion of rule by popular consent is that parliamentary politics, according to some political scientists, is seen as less relevant for voters, while other forms of participation (e.g., signing petitions, participating in demonstrations) have become more important (e.g., Bjørklund, 1999; Offerdal, 2003).

According to Stray (2010), the Norwegian core curriculum emphasises a cognitive approach to citizenship and learning about democracy. The core curriculum also includes elements of preparation for democratic participation (The Norwegian Directorate for Education and Training [UDIR], 1993). Under the core curriculum, all school subjects are responsible for preparing students for participation in society; however, politics and democracy as concepts and topics are particularly important in social studies. Børhaug (2008) found that the main trend among the teachers in his study was a focus on voting in elections as the main political and democratic activity. In Norway, social studies is an obligatory course during the first year of upper secondary education in the academic track. Competence aims specifically related to politics and democracy focus on political parties and institutions, opportunities for participation, pluralism and the rights of minorities, and challenges for democracy (UDIR, 2013). These also include central democratic skills, like discussing and analysing, which may contribute to the development of a more elaborate understanding of these issues.

\section{Methods}

\section{Research Design, Participants and Procedures}

This qualitative study consists of data collected in 2014-15, among 23 students in their first year of upper secondary education at three different schools in Norway. I selected the schools, all located in eastern Norway, based on purposive sampling (Palys, 2008). One school is in the highest echelon, one in the mid echelon, and one in the lower echelon of upper secondary schools in the area. With the help of their teachers, I selected students purposively to represent maximum variation in their class (Palys, 2008), including lower, average and high achievers. All the participating students (12 boys and 11 girls) followed the general study programme. The students from the lowest intake school all 
attended a general study programme combined with athletics, which has a higher intake than the rest of the school. The data material for this article involved five audio-recorded semi-structured group interviews; four groups with five students each, and one group with three students. I chose group interviews to allow students to build on each other's responses, to get a broad understanding of students' conceptions (Vaughn, Schumm, \& Sinagub, 1996), and to reach several students' perspectives in a relatively short period of time. All participants signed standard consent forms, and I anonymised all data after data collection (Creswell, 2013).

In line with an explorative approach (Kvale, 2007), I prepared a semistructured interview guide based on open-ended questions about how students would explain what democracy is (see Table 1). In addition, I asked follow-up questions requiring students to reflect on examples, contradictions and their own responses. For example, following the statements from the two boys in the third interview presented in the section Voting and Elections, I asked the students to imagine how democracy would look without considering elections, and whether they could think of other important characteristics of democracy. The interviews did not involve sensitive or personal issues that could lead the students to experience discomfort during or after their participation.

\section{Data Analysis}

I conducted three main analytic reading phases to search for patterns across the collected material. First, I read each interview transcript individually to get an overview of the material. Second, I categorised each interview based on the students' responses (descriptive coding). Lastly, I categorised the material as a whole, based on the commonalities in the preliminary categories (interpretative coding). This thematic analysis was inductive and directly based on words mentioned and explanations given by the informants, i.e., data-driven (Braun \& Clarke, 2006, p. 83). I looked for words and themes repeated by several students, and grouped those closely related (i.e., "elections” and "voting”). From these groups, I selected for further analysis those that represented their group very clearly and had received affirmative comments from other students. Despite the inductive approach, all categories presented in the section on findings represent various aspects of modern democracies and central concepts from democratic theory (e.g., Barber, 1984; Behrouzi, 2005; Cohen, 2002; Dewey, 1927; Habermas, 1995; Pateman, 1970; Rasch, 2004; Terchek \& Conte, 2001). To analyse and interpret the student data, I deduced some central concepts from the theoretical framework (see Table 1). Students' responses were then related to the various strands of the theoretical framework. In order to improve transparency, I include extracts from the interviews in the findings. 
Table 1

Examples of Interview Questions, Student Responses, and Analytical Concepts

\begin{tabular}{|l|l|l|}
\hline \multicolumn{1}{|c|}{$\begin{array}{c}\text { Examples of interview } \\
\text { questions }\end{array}$} & \multicolumn{1}{|c|}{ Student response examples } & $\begin{array}{l}\text { Overview of Analytical } \\
\text { concepts }\end{array}$ \\
\hline $\begin{array}{l}\text { How would you explain } \\
\text { the concept of } \\
\text { democracy? }\end{array}$ & $\begin{array}{l}\text { "Rule by the people ... that the ones who rule } \\
\text { should represent the people, and that we kind } \\
\text { of rule indirectly" (Girl 2-1) } \\
\text { "We have always heard that the majority } \\
\text { decides" (Girl 1-1) }\end{array}$ & $\begin{array}{l}\text { Individual preferences, } \\
\text { freedom and rights }\end{array}$ \\
Aggregation of interests \\
$\begin{array}{l}\text { Does everyone have the } \\
\text { same opportunities to } \\
\text { influence in a } \\
\text { democracy? }\end{array}$ & $\begin{array}{l}\text { "Not voting is like giving a vote to another } \\
\text { party" (Boy 2-3) }\end{array}$ & Individual preferences \\
\hline $\begin{array}{l}\text { Do we have other } \\
\text { opportunities than } \\
\text { elections to influence } \\
\text { democracy? }\end{array}$ & $\begin{array}{l}\text { "Maybe demonstrations" (Boy 2-1) } \\
\text { "We can voice our opinions in the } \\
\text { newspaper, for example" (Girl 5-1) }\end{array}$ & Self-realisation \\
\hline $\begin{array}{l}\text { Do we have any rights } \\
\text { or duties in a } \\
\text { democracy? }\end{array}$ & $\begin{array}{l}\text { "Following the human rights" (Boy 3-2) } \\
\text { "To be allowed to express and demand your } \\
\text { rights, like freedom of speech" (Boy 1-1) }\end{array}$ & Consensus \\
\hline
\end{tabular}

Note. Students are presented according to gender and group affiliation (e.g., Girl 6-3 would be girl number 3 in group 6).

\section{Findings}

Because the five groups had few major differences, I present the findings thematically based on the four main aspects of the students' conceptions of democracy. They are arranged according to what students emphasised the most, i.e., rule by the people, voting and elections, other forms of participation, and rights and responsibilities. Based on the general findings, the final section presents how the students' understanding of democracy vary from limited to more elaborate across the four thematic categories.

\section{Rule by the People}

The term folkestyre (rule by the people) constituted the students' main association and explanation of the concept of democracy. The students explained rule of the people primarily in two ways; first, as the essence of modern representative (liberal) democracies where the rulers must represent the people, and second, that this representation is strongly related to majority rule. In practice, this principle is secured through elections. The following interview excerpts illustrate this idea: 
Girl 2-2: $\quad$ Eh, rule by the people.

Boy 2-1: That the ones who rule are elected by the people, that the majority think these people are fit to rule the country.

Girl 1-1: We have always heard that the majority decides. From [when] we were little. They start with it in kindergarten, that the majority decides. Because then more people will be happy.

Girl 1-2: $\quad \ldots$ and that is fair.

Boy 5-1: Everyone can participate in decision-making, but those who are the majority can decide the most in a way.

As exemplified above, students were very clear that it is the majority group that wins and gets the power. According to the students, "the majority" is formed when "the people" vote in elections. The students did not go further in describing this majority, and made no distinction between 'the majority of the people' and 'the majority that gained power' as a consequence of elections. They argued that, when the majority has the power, more people "get their way", which they considered a fair way of organising society. Several students also compared this system to their personal lives, as highlighted below:

Boy 1-2: It's like in our everyday lives.... If you're a group that wants to do something, the majority wins.

Girl 1-2: It's like this in the classroom and with friends. It's like, the winner is the winner, and the ones who lose don't get a say in the matter.

A few students delved more deeply in nuancing the critique of rule by the people through majority rule. One student reflected that, even though the majority elected one party or a coalition of parties, the elected officials may still not have an absolute majority. In essence, some students revealed that the majority is not necessarily a static and stable entity. To sum up, when discussing the concept of democracy and its main features, students emphasised the importance of having elected leaders and the supremacy of the majority. They closely linked this to voting and elections, as presented in the next sub-section.

\section{Voting and Elections}

Students seemed to view voting in political elections as the most important form of democratic participation for reasons of (a) political equality, (b) citizens' responsibility and (c) the importance of expressing one's opinions: 
Girl 5-2: [...] There are no economic differences. No matter what condition you live in, you have the opportunity to vote because you are a part of democracy.

Boy 5-1: All votes count the same, and then every person and all people's opinions also count the same. Everyone has something to say, and everyone has value.

Boy 3-3: Not voting is like giving a vote to a different party.

Boy 3-2: [...] It doesn't take much of an effort to find a party to support. [...] And the purpose is to get the best possible cross-section of Norway's needs.

First, many students argued the main characteristic of democracy is that people have the right to vote. This, combined with the belief that every vote is equally important (which in Norway is not technically true), is the main expression of political equality. One student pointed out that, because the right to vote is free and given to everyone, it has clear advantages over other forms of participation. Students also linked this to equality in general and individuals' equal worth. Second, students described voting as an important responsibility or even duty of a country's citizens. They saw voting as a central, or even the most important, way of expressing one's opinions. A large majority of the 16-year-olds seemed to think that their influence before coming of voting age was minimal, confirming their view of the strong position of elections and voting as the main channel of political participation.

\section{Other Forms of Participation}

When specifically asked about other aspects of democracy than elections and other forms of participation than voting, many students hesitated before answering. The following quotes represent the most typical responses:

Boy 2-1: Demonstrations....

Girl 2-1: You can send an email....

Boy 2-1: $\quad$ Some people walk around collecting signatures for causes where they feel something is wrong.

Girl 2-2: $\quad$ Yes, and Facebook pages and stuff.

Some students also mentioned participation through traditional news media and membership in organisations, political youth parties and the student body council. Most students agreed that it is important for citizens to stand up for their opinions, and they recognised that action may be necessary even outside of election season. Students' ideas about participation have been included in the findings because their ideas for influencing democracy can tell us something about what they see as the central characteristics of, and consequently how they understand the concept of, democracy.

Even if students did not include discussions and debates as ways of influencing democracy, they acknowledged these as important activities in a democracy (e.g., that listening to or participating in debates and discussions 
allows one to see different perspectives). Several students also highlighted participation in discussions, including argumentation and being critical, as one of the most important things they learn in school in preparation for political participation.

\section{Rights and Responsibilities}

Based on the statements in this category, students were more preoccupied with the rights that are important in democracies than with the duties or responsibilities of citizens. In all the group interviews, freedom of speech was the most frequently mentioned and the most highlighted democratic right. Students related this primarily to fronting one's opinions, but also to being a part of shaping society and being able to voice criticism toward government. In general, they asserted that "you can say and mean what you want" (Boy 1-2) and that "you need to respect that people have different opinions" (Boy 1-2). In addition to free speech, some students mentioned other human rights, such as freedom of religion, liberty, freedom of thought, free and open elections, free education and central aspects of rule of law.

Their responses to whether citizens have any duties in a democratic country can be divided into three: following one's country's laws and rules, voting in elections, and respecting and being nice to other people.

\section{Limited and Elaborate Understanding of Democracy}

In the analysed material, there are clear indications of different levels of nuance and depth in students' understandings that cut across the thematic categories. Although "rule by the people" was the spontaneous definition of democracy, some students offered a more elaborated understanding, often expressed as critical comments ("rule by the people is not really a precise definition" [Boy 12]). This is primarily illustrated in attempts at questioning some of the concepts related to democracy or adding new concepts to the agreed upon definition. One student stated that "many people look at democracy and think, OK, if everyone can vote, it's a democracy ... but you have to understand that it is more than that" and "we all have a duty to maintain democracy ourselves. For example, we have to take care of the minorities" (Boy 3-2). This student showed that he could see beyond democracy as rule of the people and respect for basic human rights. He recognised that citizens have personal responsibility in their everyday lives, and that democracy is more than politics (Stray, 2010).

Some students also discussed the role of political parties and politicians more in-depth, and shed some critical light on the relationship between the majority and the minority. The following quote illustrates a more nuanced and dynamic understanding of the democratic election process: 
Well, like now, four parties rule together, and they have different opinions about many things. And in order for them to maintain the government, they have to compromise with each other, and then people may feel that they are not doing what they said they would [...]. But if people feel that what they voted for isn't happening, they will lose trust in those parties, and then they probably won't be re-elected. (Girl 5-1)

This student brought up elements of democracy related to cooperation and compromise, the relationship between elections and their aftermath, the relationship between citizens and government, and the need for voters to do more than vote for the party they agree with the most once every few years.

The main characteristic of the limited conceptualisations of democracy is the tendency for students to repeat simple and brief definitions of democracy and the main characteristics of (Norwegian) democracy. Students defined democracy in terms of freedom of expression, equal opportunities to influence democracy for all citizens and the right of the majority to rule through their representatives in Parliament. One student illustrated this when claiming that, "when more than half of Norway votes for Høyre [the Conservative Party], half the people lose their ... don't have it their way" (Girl 1-2). Other students confirmed this view, for example in the following statement: "We have always heard that the majority decides. From [when] we were little. [...] Because then more people will be happy” (Girl 1-1). These kinds of statements represent a somewhat limited, or uncritical, understanding of democracy. Implications are discussed below.

\section{Discussion}

The findings presented above indicate that the students in this study identified strongly with certain aspects of liberal democracy, such as majority rule through elections, but they also brought up elements of participatory and deliberative views of democracy, such as other forms of participation and the importance of discussions. Based on these findings, I will discuss students' understanding of democracy and some implications for teaching and teacher education in social studies.

\section{Students' Understanding of the Concept of Democracy}

A democratic practice limited to elections represents a baseline definition of democracy (Munck, 2014). A common critique of the liberal view of democracy is that it is aggregative and requires citizens only to choose between competing elite representatives. When students define democracy as "rule by the people", they refer to the origin and meaning of the word. In combination, they highlight individual rights, individual preferences, a system where the majority wins and elections as a way of finding a "cross-section" of the people's opinions. This is a close fit with liberal democratic theory, and the students' characterisation of the 
democratic citizen does to some extent take on the "reactive role" described by Behrouzi (2005). This perspective also corroborates Børhaug’s (2008) findings from Norwegian classrooms. An explanation for the strong position of elections can be found both in what goes on in the social studies classroom, and in the strong focus on politicians and elections in the media and society. Many scholars would argue that this perspective is not enough, that democracy consists of much more than electing representatives and that broader citizen participation is desirable and necessary (Behrouzi, 2005; Dewey, 1927; Munck, 2014).

Even though the students strongly supported a majority conception of democracy, several of them also talked about fairness. Majority decisions are often considered the fairest alternative in large-scale societies, but fairness can also represent participatory and deliberative views on democracy because what is fair can also mean the search for some sort of common good. According to theorists (Cohen, 2002; Dewey, 1927; Habermas, 1995), fairness can be achieved through various forms of political interaction between citizens, through deliberation, discussion and perhaps even consensus. Like Rasch (2004; see also Pateman, 1970; Dewey, 1927), several students argued that participating in and listening to discussions, in and out of school, are valuable for developing critical thinking and learning about multiple perspectives. In spite of this, they were still loyal to majority rule and simple majority decisions. To some extent, this contradicts their support for the ideal of "rule by the people", depending on how this idea is understood.

An interesting question is how much students' conceptualisations are influenced by the democratic context they live in (Davies \& Lundholm, 2011; Moodie et al., 1995). Is what they have explained simply a mirror of their "normal" and consequently less relevant for students experiencing other "normals"? Students reflected on features of democracy that are prominent in the media and in the social studies curriculum, but they also turned to more general principles and "ideas" of democracy. In addition, the Norwegian students' responses have clear commonalities with those of other Western youth (Arensmeier, 2010; Moodie et al., 1995; Sigel \& Hoskin, 1981; Szalay \& Kelly, 1982).

In the findings, I introduced the concepts of limited and elaborate understandings of democracy to supplement the theoretical concepts from democratic theory. These are primarily meant to describe students' levels of indepth understanding and ability to critically evaluate information, with the goal of moving more students in the direction of an elaborate understanding. The explanations of the students who demonstrated a limited understanding resonate with Munck's (2014) minimal definition of democracy, an electoral democracy, and may also reflect Sigel and Hoskin's (1981) findings that 58\% of adolescents gave simplistic (or even wrong) explanations of democracy, while 16\% offered more sophisticated explanations. More than favouring participatory or 
deliberative conceptions of democracy, the concepts are related to students' knowledge about how democracy works, and to central skills students are increasingly expected to master during their years in school; critical thinking, evaluating information, reflecting on challenges in society, and discussing concepts in relation to the "real" world. It is important to see these concepts as points on a scale, and not two clear-cut categories of understanding (that students either have a limited or an elaborate understanding of democracy).

This study has some limitations. One is related to the sample, and points to the need for further validation of the findings. This is an avenue for future research, employing different designs. Another limitation relates to the data collection procedures. Interviews provide limited insight into participants' thoughts and understanding, and the researcher relies on what the informants express willingly in that context. The questions I asked framed the interviews and may have influenced participants' answers, as may the presence of the other group members.

\section{Implications for Teaching and Teacher Education in Social Studies}

The findings presented in this article indicate a need to strengthen the efforts of helping students toward more elaborate understanding of the concept of democracy, including both cognitive and emotional aspects. This is in line with a recent Official Norwegian Report recommending that Norwegian education increases its focus on in-depth learning and progression in learning and understanding (Ministry of Education and Research, 2015). These efforts are also increasingly necessary in light of some of the new challenges facing many Western countries, such as increased immigration and political and social tension, which can lead to heated public debate (e.g., Hess \& McAvoy, 2015). Because these debates quickly find their way into the social studies classroom (e.g., through current events discussions and via the plethora of digitally available news and social media), they also become a pertinent matter for the teacher education meant to prepare student teachers for these classrooms.

As demonstrated above, the concept of democracy is both contested and relative (Crick, 2008; Nguyen, 2014). Thus, it is not always clear for student teachers where and how to begin curricular deliberation (Shulman, 1995), suggesting implications for teacher education. The goal is not for teacher educators to define what kind of democracy is to be taught in social studies as a school subject, but to help student teachers identify the different perspectives on concepts such as democracy, and to discuss implications of bringing these perspectives into the classroom.

Based on these findings, it seems necessary to avoid the development of what Edwards (2014) called "local dialects", where teachers adopt the teaching practices of their school instead of building on new knowledge to bridge theory and practice (Brevik, 2015, p. 71). Linking school practices to teacher education in social studies requires programmes to engage student teachers in the 
educational discourse of defining central concepts. This is not merely an educational discourse, but also a public discourse in the media and between politicians, which makes it more important to take ownership of in teacher education. Another more relevant reason is the relationship between the social sciences as scientific disciplines and social studies as a school subject. Social studies teachers have diverse academic backgrounds (e.g., political science, sociology, social anthropology, human geography) and bring with them various perspectives on the school subject they are to teach. Precisely because this diversity brings vitality to the field, teacher education is a vital binding link between various academic disciplines and the school subject (Eriksen \& Lund, 2016). In addition, student teachers may face difficulties in translating their newly acquired knowledge in the academic discipline into pedagogical content knowledge (Shulman, 1986) or professional knowledge and instruction in social studies (Stengel, 1997).

This knowledge is important for two major reasons. First, for teachers to evaluate critically what kind of conceptual view on democracy they teach. Second, if teachers and student teachers do not actively decide which aspects to teach and how to introduce their students to scientific concepts and practices like democracy, others, for example textbook authors (Blikstad-Balas, 2014), will make these decisions for them. In other words, this notion is strongly related to social studies teachers' and student teachers' professional development.

\section{Conclusion}

In this article, I have argued that schools and teachers are obligated to teach their students about democracy and give them experience with democratic practices. It is important, therefore, to reflect on and explore how students understand such a central concept as democracy.

Learning about the concept of democracy is also essential for students' outof-school democratic participation. A narrow conception of democratic practice may lead to more narrow political participation. The students in this study identified strongly with certain aspects of liberal democracy, but they also brought up elements of participatory and deliberative views of democracy. This knowledge can contribute to finding ways of broadening students' views on what democracy is and, perhaps more importantly, what it can be. It also highlights the importance of continuing working on central skills, such as critical thinking, in order to plan teaching that fosters elaborate understanding of concepts and social issues.

One central implication is that teacher educators in social studies need to engage actively in discussing and defining core concepts with their students. This engagement is related to supporting student teachers' professional development and, through this, developing students' opportunities for 
democratic participation. Such a dual focus can provide a knowledge base helping student teachers in their professional development, especially in their first years as practicing teachers.

\section{References}

Arensmeier, C. (2010). The democratic common sense. Young Swedes' understanding of democracy - Theoretical features and educational incentives. Young, 18(2), 197-222. Retrieved from http://you.sagepub.com/content/18/2/197.full.pdf+html

Arter, D. (1999). Scandinavian politics today. Manchester: Manchester University Press.

Barber, B. (1984). Strong democracy: Participatory politics for a new age. Berkeley, CA: University of California Press.

Behrouzi, M. (2005). Democracy as the political empowerment of the people: The betrayal of an ideal. Lanham, MD: Lexington Books.

Bjørklund, T. (1999). Et lokalvalg i perspektiv: Valget i 1995 i lys av sosiale og politiske endringer [A Local Election in Perspective: the 1995 Election in Light of Social and Political Changes]. Oslo: Tano Aschehoug.

Blikstad-Balas, M. (2014). Lærebokas hegemoni - et avsluttet kapittel? [The Hegemony of the Textbook: A Finished Chapter?] In R. Hvistendahl, A. Roe, \& F. Hertzberg (Eds.), Alle tiders norskdidaktiker: Festskrift til Frøydis Hertzberg på 70-årsdagen den 18. november 2014 [Essays in Honour of Professor Frøydis Hertzberg on her $70^{\text {th }}$ Birthday, 18 November 2014] (pp. 325-347). Oslo: Novus.

Braun, V., \& Clarke, V. (2006). Using thematic analysis in psychology. Qualitative Research in Psychology, 3(2), 77-101. Retrieved from http://www.tandfonline.com/doi/pdf/10.1191/1478088706qp063oa

Brevik, L. M. (2015). How teachers teach and readers read: Developing reading comprehension in English in Norwegian upper secondary school, No. 221 (Unpublished doctoral dissertation). University of Oslo, Oslo.

Børhaug, K. (2008). Educating voters: Political education in Norwegian upper-secondary schools. Journal of Curriculum Studies, 40(5), 579-600. Retrieved from http://www.tandfonline.com/doi/pdf/10.1080/00220270701774765

Canache, D. (2012). Citizens' conceptualizations of democracy. Comparative Political Studies, 45(9), 1132-1158. Retrieved from http://cps.sagepub.com/content/45/9/1132.full.pdf+html

Cohen, J. (2002). Deliberation and democratic legitimacy. In D. Estlund (Ed.), Democracy (pp. 8-106). Malden, MA: Blackwell.

Concept. (2015). In Cambridge Dictionaries Online. Retrieved from http://dictionary.cambridge.org/dictionary/english/concept

Creswell, J. (2013). Qualitative inquiry \& research design: Choosing among five approaches (3rd ed.). Los Angeles: Sage.

Crick, B. (2008). Democracy. In J. Arthur, I. Davies, \& C. Hahn (Eds.), The SAGE handbook of education for citizenship and democracy (pp. 13-20). Los Angeles: Sage.

Dahl, R. (2001). Democracy. In N. Smelser \& P. B. Baltes (Eds.), International encyclopedia of social \& behavioral sciences (pp. 3405-3408). Amsterdam: Elsevier.

Dalton, R., Shin, D., \& Jou, W. (2007). Understanding democracy: Data from unlikely places. Journal of Democracy, 18(4), 142-156. Retrieved from https://muse.jhu.edu/journals/journal_of_democracy/v018/18.4dalton.html 
Davies, P., \& Lundholm, C. (2011). Students' understanding of socio-economic phenomena: Conceptions about the free provision of goods and services. Journal of Economic Psychology: Research in Economic Psychology and Behavioral Economics, 33(1), 79-89. Retrieved from http://www.sciencedirect.com/science/article/pii/S0167487011001218

Dewey, J. (1927). The public and its problems. London: George Allen \& Unwin.

The Economist Intelligence Unit. (2015). The Democracy Index. Democracy and its discontents. Retrieved from http://www.eiu.com/Handlers/WhitepaperHandler.ashx?fi=Democracy-index2014.pdf\&mode=wp\&campaignid=Democracy0115

Edwards, A. (2014). Learning from experience in teaching: A cultural historical critique. In V. Ellis \& J. Orchard (Eds.), Learning teaching from experience: Multiple perspectives, international contexts (pp. 69-74). London/New York: Bloomsbury.

Eriksen, T. M., \& Lund, A. (2016). Teacher education as transformation: Some lessons learned from a centre of excellence in education. Acta Didactica Norge, this issue.

Habermas, J. (1995). Tre normative demokratimodeller [Three Normative Models of Democracy]. In E. O. Eriksen (Ed.), Deliberativ politikk: demokrati i teori og praksis [Deliberative Politics: Democracy in Theory and Practice] (pp. 30-45). Oslo: TANO.

Hess, D., \& McAvoy, P. (2015). The political classroom. Evidence and ethics in democratic education. New York: Routledge.

Kvale, S. (2007). Doing interviews. SAGE Publications, Inc. Retrieved from http://srmo.sagepub.com/view/doing-interviews/SAGE.xml

Lijphart, A. (1999). Patterns of democracy: Government forms and performance in thirty-six countries. New Haven, CT: Yale University Press.

Mikkelsen, R., Fjeldstad, D., \& Lauglo, J. (2011). Morgendagens samfunnsborgere: Norske ungdomsskoleelevers prestasjoner og svar på spørsmål i den internasjonale demokratiundersøkelsen ICCS [Citizens of Tomorrow: Norwegian Lower-Secondary Students' Performance and Answers to Questions in the International Democracy Study ICCS] (Vol. 2/2011, Acta didactica). Oslo: University of Oslo, Department of Teacher Education and School Research.

Ministry of Education and Research. (2015). The school of the future - Renewal of subjects and competences (NOU 2015: 8). Retrieved from https://www.regjeringen.no/en/dokumenter/nou-2015-8/id2417001/?ch=1\&q

Moodie, E., Markova, I., \& Plichtova, J. (1995). Lay representations of democracy: A study in two cultures. Culture and Psychology, 1, 423-453. Retrieved from http://cap.sagepub.com/content/1/4/423.full.pdf+html

Munck, G. (2014). What is democracy? A reconceptualization of the quality of democracy. Democratization, 1-26. Retrieved from http://www.tandfonline.com/doi/pdf/10.1080/13510347.2014.918104

Nguyen, H. (2014). On democratic theories. Philosophy Now, 101, 11-13.

The Norwegian Directorate for Education and Training. (1993). Core Curriculum and the Quality Framework. Retrieved from http://www.udir.no/globalassets/upload/larerplaner/generell_del/5/core_curriculum_englis $\underline{\text { h.pdf }}$

The Norwegian Directorate for Education and Training. (2013). Social studies subject curriculum (SAF1-03). Retrieved from http://www.udir.no/kl06/SAF103/Hele/Kompetansemaal/?lplang=eng

Offerdal, A. (2003). Politisk deltakelse - Er den så nøye da? [Political Participation - Does it really matter?] Norsk Statsvitenskapelig Tidsskrift, 19(03), 361-376. 
Ottemoeller, D. (1998). Popular perceptions of democracy: Elections and attitudes in Uganda. Comparative Political Studies, 31(1), 98-124. Retrieved from http://cps.sagepub.com/content/31/1/98.full.pdf+html

Palys, T. (2008). Purposive sampling. In L. M. Given (Ed.), The SAGE encyclopedia of qualitative research methods (pp. 698-699). Thousand Oaks, CA: SAGE Publications, Inc. Retrieved from http://knowledge.sagepub.com/view/research/n349.xml

Pateman, C. (1970). Participation and democratic theory. Cambridge: Cambridge University Press.

Rasch, B. E. (2004). Innledning [Introduction]. In B. E. Rasch \& K. Midgaard (Eds.), Demokrati: Vilkår og virkninger [Democracy: Conditions and Consequences] (2nd ed., pp. 11-22). Bergen: Fagbokforlaget.

Schulz, W., Ainley, J., Fraillon, J., Kerr, D., \& Losito, B. (2010). Initial findings from the IEA International Civic and Citizenship Study. Amsterdam: International Association for the Evaluation of Educational Achievement (IEA). Retrieved from http://iccs.acer.edu.au/uploads/File/Reports/ICCS_10_Initial_Findings.pdf

Schumpeter, J. (1994). Capitalism, socialism and democracy. London: Routledge.

Selle, P., \& Østerud, Ø. (2006). The eroding of representative democracy in Norway. Journal of European Public Policy, 13(4), 551-568. Retrieved from http://www.tandfonline.com/doi/pdf/10.1080/13501760600693929

Shulman, L. S. (1986). Those who understand: Knowledge growth in teaching. Educational Researcher, 15(2), 4-14. Retrieved from http://www.jstor.org/stable/pdf/1175860.pdf?acceptTC=true

Shulman, L. S. (1995). To see it is to psychologize it. Paper presented as The John Dewey Lecture at the annual meeting of the John Dewey Society and the American Educational Research Association, San Francisco, CA.

Sigel, R., \& Hoskin, M. (1981). The political involvement of adolescents. New Brunswick, NJ: Rutgers University Press.

Stengel, B. (1997). “Academic discipline” and “school subject”: Contestable curricular concepts. Journal of Curriculum Studies, 29(5), 585-602. Retrieved from http://www.tandfonline.com/doi/pdf/10.1080/002202797183928

Stray, J. H. (2010). Demokratisk medborgerskap i norsk skole? En kritisk analyse [Democratic Citizenship in the Norwegian School System? A Critical Analysis] (Unpublished doctoral dissertation). Oslo: University of Oslo. Retrieved from https://www.duo.uio.no/bitstream/handle/10852/30460/AvhandlingJHStray.pdf?sequence $=1 \&$ isAllowed $=\mathrm{y}$

Szalay, L. B., \& Kelly, R. M. (1982). Political ideology and subjective culture: Conceptualization and empirical assessment. American Political Science Review, 76, 585-602. Retrieved from http://www.jstor.org/stable/pdf/1963733.pdf

Terchek, R., \& Conte, T. (2001). Theories of democracy: A reader. Lanham, MD: Rowman \& Littlefield.

Tjønneland, E. (2011). Begrep - filosofi [Concept - Philosophy]. In Store norske leksikon [the Great Norwegian Encyclopedia]. Retrieved from https://snl.no/begrep\%2Ffilosofi

Torney, J., Oppenheim, A. N., \& Farnen, R. F. (1975). Civic education in ten countries: An empirical study. New York: John Wiley.

Torney-Purta, J. (2002). Patterns in the civic knowledge, engagement, and attitudes of European adolescents: The IEA civic education study. European Journal of Education, 37(2), 129-141. Retrieved from http://onlinelibrary.wiley.com/doi/10.1111/14673435.00098/epdf 
Vaughn, S., Schumm, J., \& Sinagub, J. (1996). Focus group interviews in education and psychology. Thousand Oaks, CA: SAGE Publications, Inc. Retrieved from http://sk.sagepub.com/books/focus-group-interviews-in-education-and-psychology

Østerud, Ø., \& Selle, P. (2006). Power and democracy in Norway: The transformation of Norwegian politics. Scandinavian Political Studies, 29(1), 25-46. Retrieved from http://onlinelibrary.wiley.com/doi/10.1111/j.1467-9477.2006.00140.x/epdf

\footnotetext{
${ }^{1}$ Students' democratic attitudes and support for democratic values on one hand, and students' conceptions of democracy on the other, are arguably related. For the purposes of this article, the two issues are kept distinct from each other based on the observation that democratic values and attitudes are well-documented in the literature, and the fact that students' understanding of the concept of democracy as defined on pages 2-3 (i.e., ideas about central features and characteristics) constitutes the focus of the empirical investigation the article builds on.
} 